Spetalen, H. (2017). Teori og praksis i yrkesfaglige læreplaner - myter og realiteter. Scandinavian Journal og Vocations in Development

http://dx.doi.org/10.7577/sjvd.2264

Peer reviewed article

\title{
Teori og praksis i yrkesfaglige læreplaner - myter og realiteter
}

Forfatter:

Halvor Spetalen

Høgskolen i Oslo og Akershus, Fakultet for lærerutdanning og internasjonale studier, Institutt for yrkesfaglærerutdanning

Halvor.spetalen@hioa.no

Nøkkelord: Yrkesopplæring, teori, praksis, læreplan, restaurant- og matfag 


\title{
Sammendrag
}

Andelen praksis og teori i yrkesopplæringen er et tema som stadig diskuteres i media og ulike fagfora. Sentralt i denne diskusjonen står to påstander: (1) At andelen fellesfag er blitt for stor i forhold til tidligere, og (2) at yrkesopplæringen er blitt mer teoriorientert etter innføringen av Kunnskapsløftet.

Formålet med denne artikkelen er å problematisere disse to påstandene gjennom et systematisk litteraturs $\varnothing \mathrm{k}$ og dokumentanalyse av læreplaner i utdanningsprogrammet restaurant- og matfag for perioden 1976-2006.

Selv om hovedvekten er lagt på fag- og timefordeling i læreplanene innenfor restaurant- og matfag, kan innholdet i artikkelen generaliseres ut over dette da læreplanene i ulike perioder hadde samme organisering og oppbygging.

Resultatet av analysen viser at andelen felles allmenne fag i læreplanene har styrket seg på bekostning av de yrkesfaglige programfagene i perioden fra 1976 til 2006, men om dette har ført til at den skolebaserte yrkesopplæringen er blitt mer klasseroms- og teoriorientert, må likevel problematiseres og nyanseres. Læreplananalysen gir lite hold for denne påstanden.

\begin{abstract}
The proportion of practice and theory in vocational education is a topic that is constantly discussed in the media as well as different professional forums. Two central issues prevail in these discussions:

1. That the proportion of common core general subjects has increased compared to earlier.

2 . That vocational education and training has become more theoretical, following the implementation of the Norwegian National Curriculum for Knowledge Promotion (LK06).
\end{abstract}

The purpose of this article is to discuss these issues through both a systematic literature search and document analysis of the curricula in the educational programs for restaurant and food subjects between 1976 and 2006.

Although the emphasis is on subjects and allocated teaching hours in the curricula for restaurant and food subjects, the article is also relevant to other vocational curricula as these have had, at various times, a similar structure.

The results of the analyses show that the proportion of common core general subjects has been strengthened at the cost of vocational content in the period 1976- 2006. However further discussions and distinctions would need to be addressed in order to say if this has led to school based vocational education becoming more classroom- and theory orientated. The curriculum analysis does not give sufficient indication to conclude this.

Key words: Vocational training, theory, practice, curriculum, restaurant- and food processing 


\section{Bakgrunn}

I den offentlige debatten er ofte fordelingen mellom såkalt teori og praksis i den skolebaserte yrkesopplæringen et tema (Lysberg \& Kihl, 2015; Sjøberg, 2014; Solheim, 2009), uten at disse begrepene nødvendigvis blir definert eller forklart. Uten at det forekommer empirisk belegg, blir det for eksempel hevdet at innføringen av Kunnskapsløftet har ført til en mer teoretisk yrkesopplæring i Norge (Lotherington, 2008; Rød ungdoms landsstyre, 2013). Debatten dreier seg derfor både om andelen av fellesfag i forhold til programfag i læreplanene, men også om hvordan innholdet og laeringsaktivitetene i de yrkesfaglige programfagene best bør organiseres (Hegna, Smette, Dæhlen \& Wollsceid, 2012).

Denne forskjellen har betydning fordi ulik forståelse av spørsmålet om teori-praksis i yrkesopplæringen kan føre til svært ulike initiativer og tiltak. Om problemet forstås som at elevene møter for mye teori i yrkesopplæringen (Aadland, 2011; Oppen, 2012), kan eventuelle initiativer bli annerledes enn om problemet forstås slik at det ikke nødvendigvis er andelen teori som gjør at elevene faller ut, men hvordan teorien formidles (Buland, 2010) eller teoriens manglende yrkesrelevans (Utvær \& Rokkones, 2012; Dahlback, Hansen, Haaland \& Sylte, 2010, Hiim, 2013)?

I denne artikkelen vil jeg benytte kvantitativ læreplananalyse for å belyse to spørsmål:

1. Er andelen fellesfag blitt større i forhold til de yrkesfaglige programfagene i den skolebaserte yrkesopplæringen i tiden fra 1976 og til innføringen av Kunnskapsløftet i 2006 innenfor utdanningsprogrammet restaurant- og matfag?

2. Har utformingen av de formelle læreplanene lagt føringer for en mer teoriorient skolebasert yrkesopplæring i perioden 1976 til 2006 ?

Wilfred Wassenden (2001) skriver at andelen fellesfag også kunne oppleves for stor i den skolebaserte yrkesopplæring i læreplaner før Reform 94. I denne artikkelen går jeg videre og viser fordelingen mellom programfag og fellesfag i perioden 1976 til 2006, og hvordan utformingen av de formelle læreplanene i perioden har bidratt til føringer for undervisning og elevenes læringsaktiviteter. Denne oversikten kan bidra til en kunnskapsbasert debatt knyttet til spørsmålet om læreplanene i denne perioden har lagt føringer for en yrkesopplæring med større vekt på fellesfag og yrkesteori enn på det vi kan kalle praktiske yrkesrettede læringsaktiviteter. Det konkrete eksempelet jeg bruker i denne artikkelen er læreplaner i 
restaurant- og matfag, men felles organisering av læreplaner gjør at innholdet er representativt ut over dette utdanningsprogrammet.

Analyseperspektivet i denne artikkelen er dermed først og fremst en analyse av fag- og timefordelingen i de formelle laereplanene over en tidsperiode. Andre forhold som bakgrunnen for lareplanene, hvordan yrkesfaglarere oppfatter lareplanene, hvordan yrkesfaglarere gjennomfører lareplanene og hvordan elevene erfarer lareplanene (Goodlad,

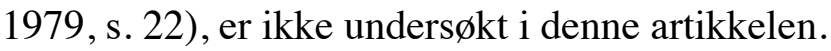

\section{Teori-praksis begrepet}

Hva begrepet teori og praksis innebærer er en større epistemologisk diskusjon, men begrepet teori kan antydningsvis forstås som kunnskap om noe. Man kan «se på» begreper, prosesser, handlinger, gjenstander, materialer og så videre uten å interagere med praksisfeltet. Distinksjonen mellom knowing that og knowing how (Ryle, 1949) kan illustrere noe av forskjellen mellom hva teori og praksis innebærer i et yrkesopplæringsperspektiv uten at denne distinksjonen er uttømmende. Jeg forstår imidlertid teoribegrepet slik at et «teortisk vetande» kan skilles fra den praktiske og målrettede handlingsverden» (Molander, 1993, s. 66) og blir en form for tilskuerkunnskap (Eikeland, 2006) frikoblet fra handlingstvangen i praksisfeltet (Dale, 1993). Dette skillet mener både Duesund (1995) og Engelsrud (2006) er en arv fra filosofen Descartes.

Praksis, på den annen side, knyttes gjerne til konkrete og observerbare handlinger og aktiviteter. Praksis kan forstås som: «... a set of actions, embodied, materially mediated arrays of human activity centrally organized around shared practical understanding» (Schatzki, Knorr-Cetina \& Savigny, 2001, s. 2, 59). Praksisbegrepet oppfattes dermed gjerne som kontekstuelt, pragmatisk, realistisk og virkelighetsnært i motsetning til det teoretiske, abstrakte, normative og ideelle.

Diskusjonen omkring forholdet mellom teori og praksis i yrkesfag er likevel på mange måter en skinndiskusjon fordi det er vanskelig å hevde at yrkespraksis er fri for teoretisk kunnskap. Selv om det i vesten er etablert et dualistisk skille mellom teori og praksis (Fuglestad, 1996), vises yrkesutøverens kunnskap i handlingen (Molander, 1993) og blir dermed et utgangspunkt for både artikulasjon og refleksjon i velfungerende yrkespraksis (Eikeland, 2006; Schön, 
1983). Lars Løvlie (1974) argumenterer for eksempel for at handling (praksis) konstitueres av tre elementer: Den teoribaserte begrunnelsen, den praktiske begrunnelsen som bygger på erfaringer og den praktiske rettferdiggjøringen som bygger på etiske overveielser og moralske beslutninger. Praksis består derfor ikke av handlinger alene, men også av teoretiske og praktiske begrunnelser samt en praktisk rettferdiggjøring.

I en skolebasert yrkesopplæring varieres det generelt mellom tre læringsarenaer; klasserommet, verkstedet og ekstern praksis. Undervisning i teori som «tilskuerkunnskap» velger jeg her å knytte til det som skjer av undervisning og læringsaktiviteter i klasserommet, mens praksis handler om det som skjer i skolens verksteder eller i arbeidslivet for $\emptyset$ vrig, noe som oppfattes som den «egentlige» og riktige formen for yrkesopplæring (Solberg, 2014). At «yrkesopplæringen er blitt for teoriorientert» kan derfor forstås som at elevene har for mye fellesfag og/eller tilbringer for mye tid med «skolske» aktiviteter i klasserommet. Det er likevel verdt å nevne at det er en uheldig forenkling å si at alt som skjer i klasserom er «teori». Et eksempel: Når restaurant- og matfagelever skriver en meny i programfaget «Råstoff og produksjon» er det udiskutabelt en yrkesrelevant praksis, men er det teori dersom de samme elevene skriver menyene i fellesfaget norsk?

Teori-praksis diskusjonen er derfor et uklart område jeg ikke velger å utdype nærmere, bare konstatere at implisitte forforståelser gjør det lett å snakke forbi hverandre. Debatten kan på samme tid handle om fordelingen mellom fellesfag og programfag i yrkesopplæringen, om relevansen av innholdet i yrkesopplæringen og om hvordan undervisningen i den skolebaserte yrkesopplæringen best bør gjennomføres.

\section{Læreplaner i yrkesfag}

Til forskjell fra læreplanen i utdanningsprogrammet studiespesialisering, er læreplanene i de yrkesfaglige utdanningsprogrammene delt i to bolker. På den ene siden har vi den funksjonsbaserte delen som er strukturert omkring sentrale arbeidsfelt og yrkesfunksjoner snarere enn skolefag og vitenskapsdisipliner (Hiim \& Hippe, 2001). «Det er altså ikke vitenskapene eller «teoriene» som er sentrum, men yrkets kjerne, arbeidsoppgaver, problemområder og tema knyttet til og rundt denne kjernen» (Solheim, 2001, s. 28). Dette er læreplanens yrkesfaglige del, gjerne kalt studieretningsfag eller programfag. Lærerplanene i 
yrkesfaglige utdanningsprogrammer inneholder imidlertid også felles allmenne fag som er organisert etter fagdisipliner. For eksempel norsk, naturfag og kroppsøving. Denne delen kalles felles allmenne fag eller bare fellesfag. Innholdet i yrkesfaglige læreplaner for utdanningsprogrammer er derfor en blanding av yrkesspesifikke fagområder og allmenne fag der styrkeforholdet varierer over tid.

I et historisk perspektiv viser Wilfred Wasenden den prosentvise fordelingen mellom antall undervisningstimer brukt til yrkesfagene og timer brukt til allmennfagene i perioden 19461976 (Wasenden, 2001, s. 14).

Tabell 1

Prosentvis fordeling av undervisningstimetallet i yrkesfaglige læreplaner for perioden 19461976

\begin{tabular}{|l|r|r|r|r|}
\hline & Plan 1946 & Plan 1949 & Plan 1963 & Plan 1970-1976 \\
\hline $\begin{array}{l}\text { Yrkesfag (studieretningsfag) med } \\
\text { funksjonsbasert innhold }\end{array}$ & $77,40 \%$ & $73,10 \%$ & $70,20 \%$ & $71,40 \%$ \\
\hline Allmennteoretiske fag inkl. kroppsøving & $22,70 \%$ & $26,90 \%$ & $29,80 \%$ & $28,60 \%$ \\
\hline
\end{tabular}

Tabell 1 er en sammenfatning og viser at fordelingen mellom undervisningstimer knyttet til yrkesfag og undervisningstimer knyttet til felles allmenne fag lå relativt fast i perioden fra 1946 til 1976, dog med et noe sterkere vektlegging av allmennteoretiske fag utover i perioden.

Videre vil jeg utdype hvordan forholdet mellom yrkesfag og allmennfag har utviklet seg i læreplanene for perioden fra og med læreplanen i 1976 og til innføringen av Kunnskapsløftet i 2006.

\section{Metode}

Innholdet i denne artikkelen er basert på et systematisk litteratursøk og dokumentanalyse. Et systematisk litteratursøk innebærer søking etter litteratur på strukturert måte som ideelt sett fører fram til en litteraturoversikt uten bias og som er komplett og reproduserbart (Kristiansen \& Hjørland, 2013, s. 60). I dette arbeidet må det selvfølgelig gjøres en avgrensning som innebærer å velge ut litteratur basert på problemstilling og forfatterens forforståelse for hva som er interessant og relevant. Søket kan utføres som et vertikalt søk der det søkes etter dokumenter man kjenner, men ikke er i besittelse av, eller et emnesøk dersom man søker 
dokumenter man ikke kjenner den konkrete eksistensen av (Kristiansen \& Hjørland, 2013, s. 59). I denne artikkelen har jeg benyttet begge disse formene. Søk etter aktuelle læreplaner har karakter av å være et vertikalt søk, mens søk etter oppfatningen av teori- og praksisfordelingen i yrkesopplæringen har vært et emnesøk. I dette emnesøket benyttet jeg søkerordene: «Teori», «praksis», «læreplan», «yrkesfag» og «yrkesopplæring»sammen, og i ulike kombinasjoner. Søket ble gjennomført både som fritekstsøk i Google og i Google Schoolar, Idunn, Norart og Oria i perioden 19. til 30. oktober 2015. Litteratur der alle søkerordene ga treff, ble prioritert. Resultatet av søket ga alt fra avisartikler, tidsskriftartikler, rapporter, antologier og doktorgradsavhandlinger.

Begrepet dokumentanalyse reserveres gjerne til det å analysere dokumentene som er skrevet for et annet formål enn det som omfattes av forskningsprosjektet. Begrepet gir også assosiasjoner til offentlige skrifter til forskjell fra for eksempel litterære skrifter (Thagaard, 2009, s. 62). Offentlige skrifter innebærer i denne artikkelen offentlige styringsdokumenter og læreplaner for perioden 1976-2006. Analysen av innholdet i disse læreplanene er først og fremst av kvantitativ karakter (Lindgren, 2001, s. 268) der fordelingen mellom undervisningstimene i programfag og fellesfag er talt opp og oppsummert i tabeller.

\section{Fag og timefordeling i utdanningsprogrammet Restaurant- og matfag}

Å lage en oversikt over fag- og timefordeling fra 1976 og fram til i dag omfatter i hovedtrekk innholdet i tre læreplaner. Disse læreplanene viser fag- og timefordelingen før Reform 94 (L 76), etter Reform 94 (R 94) og fordelingen etter Kunnskapsløftet i 2006 (LK 06). Med fag- og timefordeling forstås i hovedtrekk fordelingen mellom antall undervisningstimer i programfag og fellesfag.

I de påfølgende oversiktene vises fag- og timefordeling i GK/VK1 kokkfag før Reform 94, GK Hotell- og næringsmiddelfag etter Reform 94 og Vg1/Vg2 i restaurant- og matfag etter Kunnskapsløftet. Det er også verdt å merke seg at fag og timefordelingen i 1976-planen ikke var lik for alle de yrkesfaglige studieretningene. Læreplanen jeg benytter var gjeldende for håndverks- og industrifagene, her representert ved kokkfag. Husholdningsfag/husflid og handel- og kontorfag hadde en annen fag- og timefordeling. 


\section{Fag- og timefordeling før Reform 94}

Da de yrkesrettede læreplanene ble tatt i bruk fra 1976, bidro dette til at den grunnleggende teoriorienterte yrkesutdanningen ble langt sterkere fagrettet enn den tidligere hadde vært $\mathrm{i}$ verkstedskolene (Wasenden, 2001, s. 15). Fra en fellesfagsandel på rundt 28 \% (se tabell 1) sank andelen undervisningstimer brukt til felles allmenne fag til $11 \%$ i grunnkurs og $15 \%$ i videregående kurs.

Tabell 2

Sammenslått fag- og timefordeling i perioden 1976-1993. Uketimer. Prosentfordeling.

\begin{tabular}{|l|l|l|l|l|}
\hline & Grunnkurs & \% & Videregående kurs & $\%$ \\
\hline Felles allmenne fag & 4 & 11 & 6 & 15 \\
\hline Studieretningsfag inkl. valgfag & 31 & 89 & 34 & 85 \\
\hline Totalt & 35 uketimer & 100 & 40 uketimer & 100 \\
\hline
\end{tabular}

(Lareplan for den videregående skole. Del 1. Generell del., 1983; Lareplan for den videregående skole. Del 1. Genrell del., 1976; Møllen, 2008)

Tabell 2 viser at felles allmenne fag omfattet mellom 11 og 15 prosent av uketimene for elever som gjennomførte grunnkurs og videregående kurs for kokker i perioden 1976 til 1994. Selv om enkelte av studieretningsfagene hadde karakter av å være teoriorienterte (undervist i klasserom), var likevel andelen studieretningsfag adskillig sterkere representert i planverket enn det som tidligere hadde vært tilfelle og det som vises i senere planverk. Det som generelt kjennetegner læreplanene fra denne tiden er faglig spesialisering yrke for yrke, noe som også førte til enkelte negative konsekvenser. Dette viste seg blant annet ved at elever vandret i for stor grad horisontalt fra grunnkurs til grunnkurs som førte til dårlig gjennomstrømning. Et mangfold av læreplaner gjorde også opplæringen uoversiktlig og det var kompliserte og uoversiktlige regler for generell og spesiell studiekompetanse (Engelsen, 1998; Kirke, undervisnings- og forskningsdepartementet, 1996; St. meld. nr. 33 1991-1992). Dette førte til et behov for reformer i videregående opplæring. Svaret ble Reform 94.

\section{Fag- og timefordeling etter Reform 94}

Reform 94 ble en omfattende reform som blant annet skulle sikre lik rett til utdanning, et felles nasjonalt kunnskaps-, verdi og kulturgrunnlag, kunnskap av høy kvalitet, bestandighet og relevans, mulighet for lokal tilpasning, større grad av målstyring og god faglig-, pedagogisk- og organisatorisk- sammenheng i utdanningssystemer (St. meld. nr. 33, 1991- 
1992, s. 7). Det ble lagt vekt på å gi en bred opplæring som skulle gi grunnlag for utvikling og videre læring etter skiftende behov (Kirke-, undervisnings- og forskningsdepartementet, 1996).

Av konkrete endringer ble tilbudsstrukturen endret ved å redusere antall grunnkurs fra 113 til 13 (St. meld. 30 2003-2004) og spesialiseringen skulle skje i VK1. Normalordningen i yrkesopplæringen ble to år i skole og to års læretid i bedrift (2+2-modellen), og det ble utviklet en felles læreplanstruktur for alle studieretningene (St. meld. nr. 33 (1991-1992).

Tabell 3

Sammenslått fag- og timefordeling i perioden 1994-2005. Uketimer. Prosentfordeling

\begin{tabular}{|l|l|l|}
\hline & Grunnkurs & \% \\
\hline Felles allmenne fag & 11 & 31 \\
\hline Studieretningsfag & 24 & 69 \\
\hline Totalt & 35 uketimer & \\
\hline
\end{tabular}

(Lareplan for videregående opplaring. Studieretning for hotell- og naringsmiddelfag. Studieretningsfagene $i$ grunnkurs hotell- og naring smiddelfag, 1993)

Oversikten i tabell 3 viser at felles allmenne fag har hatt en betraktelig prosentvis $\varnothing \mathrm{kning} \mathrm{i}$ forhold til fag- og timefordelingen fra før Reform 94. Før 1994 var andelen felles allmenne fag $11 \%$ av undervisningstimene (se tabell 2), mens etter innføringen av Reform 94 ble denne prosenten $\varnothing \mathrm{kt}$ til $31 \%$. Dette skyldes i første rekke innføringen av flere allmennfag, men også at det som tidligere var yrkesrettede fellesfag i studieretningsfagene ble allmenngjort og fjernet som studieretningsfag.

Reorganiseringen av tilbudsstrukturen i yrkesopplæringen etter 1994 reduserte tendensen til kryssløp, men økte ikke nødvendigvis gjennomstrømningen (Lindbekk, 2012). I oppsummeringen av NIFUs evaluering av Reform 94 uttrykkes det at det bør gis bedre og mer fleksible tilbud til søkere uten rett til opplæring, det må sikres rett til å bruke lengere tid for dem som trenger det, samarbeidet med næringslivet må intensiveres, undervisningsform, metode og -kvalitet må vurderes og utvikles, og læretid som gjennomføres i skole må gjøres mer attraktiv og til et fullgodt alternativ (Støren, Skjersli \& Aamodt, 1998, s. 228).

Reform 94 lyktes de første årene med å løse opp de strukturelle hindringene for at elever og lærlinger skulle kunne oppnå studie- eller yrkeskompetanse. På yrkesfaglige studieretninger ble gjennomføringen forbedret med nær 100 prosent de tre første årene etter innføringen. Utviklingen viste imidlertid at visse sider ved tilbudsstrukturen motvirket rekruttering til visse 
yrker og kompetanseområder (St. meld. 30 2003-2004). Etter hvert presset også krefter i skole og næringsliv på for å få til endring (Horneland, 2014). Også ønsket om en betydelig styrking av grunnleggende ferdigheter var en medvirkende årsak til ønsket om en ny skolereform (St. meld. 30 2003-2004). Denne styrkingen kan forstås som et oppgjør med den sosialdemokratiske enhetsskoleideologien (Stray, 2010), men også på bakgrunn av de middelmådige resultatene til norske elever på PISA-, TIMSS- og PIRLS-undersøkelsene i begynnelsen av 2000-tallet. Disse resultatene ble en vekker for både politikere, pedagoger og medier og legitimerte både innføringen og vektleggingen av de grunnleggende ferdighetene i den nye reformen som ble kalt Kunnskapsløftet (Mausethagen, 2007).

\section{Fag- og timefordeling etter Kunnskapsløftet i 2006}

For de yrkesfaglige utdanningsprogrammene betydde innføringen av Kunnskapsløftet i 2006 flere forandringer. I store trekk ble forholdet mellom fellesfag og programfag uforandret og $2+2$ modellen ble opprettholdt. Av større forandringer kan nevnes at antall grunnkurs (Vg1) ble uforandret, men mange tidligere Vk1-kurs ble slått sammen i større enheter. For restaurant- og matfag sin del ble seks Vk1-kurs slått sammen til to - Vg2 Kokk- og servitørfag og Vg2 Matfag. Disse to Vg2-kursene dekker til sammen 12 fag- og svennebrevområder.

Tabell 4

Sammenslått fag- og timefordeling fra 2006. Årstimer. Prosentfordeling

\begin{tabular}{|l|l|l|l|l|}
\hline & Vg1 & \% & Vg2 & \% \\
\hline Fellesfag & 336 & 34 & 252 & 26 \\
\hline Programfag inkludert YFF & 645 & 66 & 730 & 74 \\
\hline Totalt & $\begin{array}{l}981 \\
\text { årstimer }\end{array}$ & 100 & $\begin{array}{l}982 \\
\text { årstimer }\end{array}$ & 100 \\
\hline
\end{tabular}

(Andersen, 1999; VILBLI.NO. Fylkenes informasjonstjeneste for sфkere til videregående opplaring)

Tabell 4 viser at andelen fellesfag øker ytterligere i Vg1 i forhold til grunnkurs etter Reform 94, men reduseres noe i Vg2. Det er derfor vanskelig å slå fast at antall timer til fellesfag har $\varnothing \mathrm{kt}$ etter innføringen av Kunnskapsløftet. 


\section{Oppsummering av fordelingen mellom fellesfag og programfag i yrkesfaglige læreplaner fra perioden 1976 til 2006.}

Etter de foregående oversiktene vil jeg videre oppsummere utviklingen av andelen fellesfag og programfag i yrkesopplæringen.

For å kunne sammenlikne fag- og timefordeling fra tiden før Reform 94, etter Reform 94 og etter innføringen av Kunnskapsløftet i 2006, viser tabell 5 den prosentvise timefordeling av det vi i dag kaller fellesfag og programfag i perioden fra 1976.

Tabell 5

Prosentvis fordeling av fellesfag og programfag i yrkesopplæring i perioden 1976-2006

\begin{tabular}{|l|l|l|l|}
\hline & $\begin{array}{l}\text { Før Reform 94 } \\
1976-1 æ r e p l a n\end{array}$ & $\begin{array}{l}\text { Etter Reform 94 } \\
1994-l æ r e p l e n\end{array}$ & $\begin{array}{l}\text { Etter Kunnskapsløftet } \\
\text { 2006-læreplan }\end{array}$ \\
\hline $\begin{array}{l}\text { Felles allmenne fag } \\
\text { Fellesfag }\end{array}$ & $13 \%$ & $31 \%$ & $30 \%$ \\
\hline $\begin{array}{l}\text { Studieretningsfag/valgfag } \\
\text { Programfag/YFF }\end{array}$ & $87 \%$ & $69 \%$ & $70 \%$ \\
\hline
\end{tabular}

Oversikten i tabell 5 viser sammenslåtte prosenter for Grunnkurs/Vg1 og VK1/Vg2 i perioden 1976-2006. Etter disse tallene å dømme er det vanskelig å konkludere med at det benyttes flere timer til fellesfag etter innføringen av Kunnskapsløftet i forhold til perioden etter 1994. Andelen timer til programfag har også ligget fast i perioden etter 1994. Det som imidlertid er klart er at andelen felles allmenne fag/fellesfag økte betydelig etter innføringen av Reform 94 i forhold til perioden fra 1976-1994.

\section{Fordeling av praktisk arbeid, yrkesteori og felles allmenne fag $i$ yrkesopplæringen}

Før det eventuelt kan slås fast at yrkesopplæringen er blitt mer teoriorientert fra 1976 og frem til i dag, må noen forhold nyanseres. For eksempel hvordan fordelingen mellom praktisk arbeid, yrkesteori og felles allmennfag har endret seg i denne perioden. 
Tabell 6

Prosentvis fordeling av praktisk arbeid, yrkesteori og felles allmenne fag i yrkesopplæring fra 1976-2006.

\begin{tabular}{|l|c|c|c|}
\hline & $\begin{array}{c}\text { Før Reform 94 } \\
1976\end{array}$ & $\begin{array}{c}\text { Etter Reform 94 } \\
1994\end{array}$ & $\begin{array}{c}\text { Etter Kunnskapsløftet } \\
2006\end{array}$ \\
\hline Praktisk arbeid & $57 \%$ & $41 \%$ & $61 \% * * *$ \\
\hline Yrkesteori & $31 \% *$ & $27 \% * *$ & $11 \% * * *$ \\
\hline Felles allmenne fag & $11 \%$ & $31 \%$ & $29 \%$ \\
\hline
\end{tabular}

*Læreplanen benyttet begrepet «Yrkesteori». I dette ligger det implisitt klasseromsundervisning.

**Beregnet ut i fra 1994-læreplanens føringer om at $40 \%$ av studieretningsfagene burde undervises teoretisk.

***Tabellen viser fordeling av yrkesteori og praksis i programfagene når $80 \%$ av læreplanmålene i Vg 1 og 90

$\%$ av målene i Vg2 benytter verb som krever praktiske læringsaktiviteter i verksted eller bedrift.

Tabell 6 viser ikke bare fag- og timefordelingen i læreplanene i denne perioden, men også hvilket handlingsrom læreplanene gir til fordeling av praktisk arbeid, yrkesteoretisk undervisning og undervisning i felles allmenne fag.

Dersom det gjøres en forutsetning om at både felles allmenne fag og yrkesteori i 1976-planen stort sett ble undervist i klasserom, er det rimelig å anta at elever i denne perioden deltok i klasseromsundervisning ca. $42 \%(31+11)$ av tiden og i perioden 1994 til 2006, ca. $58 \%$ (41+27) av tiden. Læreplanen fra 1994 la altså føringer for en $16 \%$ \%ning av tiden yrkesfagelevene tilbrakte i klasserom. Det er derfor rimelig å hevde at innføringen av Reform94 innebar en mer teoriorientert yrkesutdanning dersom man forstår teori som det innhold, den undervisning og de læringsaktiviteter som skjer i klasserom.

Etter innføringen av kunnskapsløftet i 2006 inneholder læreplanene i yrkesfaglige utdanningsprogrammer ingen føringer for hvordan undervisningen bør foregå. Det er heller ikke angitt hva som er yrkesteori og hva som er praksis. Læreplanens mål er formet som kompetansemål med ulike verb som må tolkes og som deretter legger føringer for yrkesfaglærernes valg av læringsaktiviteter. En analyse av Vg1 og Vg2 læreplanmålene i utdanningsprogrammet restaurant- og matfag viser at over $80 \%$ av læreplanmålene har praksisorienterte målformuleringer. Målene inneholder for eksempel begreper som å lage, produsere, rengjøre og så videre. Under $20 \%$ av læreplanmålene benytter tekstorienterte (Hellne-Halvorsen, 2014, s. 52-53) verb som for eksempel å redegjøre, analysere og beskrive (Spetalen, Johansen \& Johnsen, 2014). Dette er begreper som egner seg bedre for 
læringsaktiviteter i klasserom enn i verksted. Slås disse prosentene sammen med andelen fellesfag, har LK06-læreplanen lagt føringer for at elevene kan tilbringe ca. $40 \%(11+29 \%$. Se tabell 6) av tiden i klasserom. Dette er en betydelig mindre andel enn i perioden 1994-2006 der tilsvarende prosentandel var $58(27+31 \%$. Se tabell 6$)$.

Uten at kompetansemålene i læreplanene antyder omfang, betyr dette at dagens læreplaner i utdanningsprogrammet restaurant- og matfag i større grad enn tidligere legger til rette for praktiske læringsaktiviteter enn det som var tilfelle før innføringen av Kunnskapsløftet.

\section{Er den skolebaserte yrkesopplæringen blitt mer teoriorientert?}

Til forskjell fra læreplanene for opplæring i yrkesfag i perioden 1946-1976 hadde læreplanen fra 1976 bare to felles allmennfag; norsk og kroppsøving. Studieretningsfagene ble derfor betydelig styrket i 1976-læreplanen. Siden studieretningsfagene yrkesteori, yrkesrettet engelsk, matematikk med bedriftslære og rettslære langt på vei ble undervist i klasserom, ble likevel ikke mer enn ca. $57 \%$ av uketimene satt av til praktisk arbeid i verksteder eller bedrifter. Selv om denne prosentandelen var høyere enn tidligere, bidro altså læreplanens innhold og føringer til at yrkesfagelevene tilbrakte nesten halve tiden i klasserom.

Etter Reform 94 ble skillet mellom felles allmenne fag og studieretningsfag skarpere, ikke minst fordi prinsippet om et felles nasjonalt kunnskaps-, verdi- og kulturgrunnlag ble sterkere vektlagt. Innholdet i allmennfagene ble mer allment og allmennfaglærere overtok også undervisningen i engelsk og matematikk. Dette var fagområder som tidligere hadde vært yrkesrettede studieretningsfag og som ofte ble undervist i av yrkesfaglærere ${ }^{1}$. Læreplanen fra 1994 anbefalte imidlertid at opptil $40 \%$ av studieretningsfagene burde undervises som yrkesteori, altså i klasserom. Slås timene i allmennfag sammen med denne andelen, antydes det her at elevene burde undervises 21 uketimer i klasserom. Da er det bare $40 \%$ av uketimene igjen til praktisk arbeid, altså en markant nedgang i forhold til før innføringen av reformen i 1994 der ca. $57 \%$ av uketimene ble satt av til praktisk arbeid i verksteder eller bedrifter.

\footnotetext{
${ }^{1}$ Fag-/yrkesfaglærere som underviste i for eksempel yrkesrettet matematikk kunne oppnå formalkompetanse i dette faget både ved den daværende Stabekk høgskole og ved Statens yrkespedagogiske høgskole.
} 
Etter innføringen av Kunnskapsløftet i 2006 er andelen fellesfag og programfag i læreplanen så å si lik fordelingen fra før Kunnskapsløftet. Begrepet yrkesteori blir ikke lenger benyttet i læreplanen og det legges ikke lenger føringer for hvor stor andel av programfagene som bør undervises teoribasert. Som nevnt tidligere, viser en analyse av læreplanmålene i utdanningsprogrammet restaurant- og matfag at over $80 \%$ av læreplanmålene har praktiske taksonomibegreper (Spetalen et al., 2014). Dette gir et potensielt handlingsrom for yrkesfaglærere til å tilrettelegge for praktiske læringsaktiviteter i verksteder eller bedrifter i ca. $80 \%$ av undervisningstimene som er avsatt til felles programfag og yrkesfaglig fordypning (YFF).

En større observasjonsunders $\varnothing$ kelse fra 2011-2014 viste imidlertid at elevene i restaurant- og matfag fremdeles tilbringer ca. $33 \%$ av skoletiden som er satt av til programfag/YFF i klasserom (Spetalen et al., 2014). Selv om altså læreplanmålene i all hovedsak er praktisk rettet, betyr dette at eleven tilbringer mer prosentvis tid i klasserommet enn det kompetansemålene i læreplanen inviterer til. Dette kan ha mange årsaker, men det kan synes som om fordelingen mellom verksted- og klasseromstid i stor grad er avhengig av skolekultur og hvordan skolene selv fordeler tiden mellom klasserom og verksted. Læreplanene etter innføringen av Kunnskapsløftet i 2006 kan derfor ikke sies å være årsaken til at elevene i restaurant- og matfag tilbringer mye tid i klasserommet. Mer forskning om hvordan og hvorfor skolene fordeler tiden mellom klasserom og verksted slik de gjør, vil kunne kaste mer lys over dette.

\section{Oppsummering og konklusjon}

Oversiktene i denne artikkelen viser tilsynelatende at fag- og timefordelingen i yrkesfag har gått i fellesfagenes favør fra 1976 og fram til i dag. Som vist i denne artikkelen, er det flere av det vi i dag kaller fellesfag som tidligere var organisert innenfor studieretningsfagene før Reform 94. I tiden før Reform 94 ble det lagt et adskillig sterkere yrkesrettet fokus og ofte undervist av yrkesfaglærere med bruk av yrkesrettede lærebøker som var spesielt tilpasset hotell- og næringsmiddelfagene. At antall timer til felles allmenne fag styrket seg betraktelig etter Reform 94, skyldes blant annet en overføring og allmenngjøring av allerede eksisterende teoriorienterte studieretningsfag. Kombinert med anbefalingen om å undervise $40 \%$ av studieretningsfagene teoriorientert, er det rimelig å hevde at nye læreplaner i Reform 94 førte 
til mer teoriorientering og klasseromsundervisning i yrkesopplæringen. Dette betyr ikke at verkstedpraksis er uten teori og klasseromsaktiviteter er fri for praksis, men mange skoler kan ha lagt større vekt på teoriorientert opplæring i klasserom enn det læreplanene la opp til.

Det er også hevdet at innføringen av Kunnskapsløftet har satt ytterligere fart på teoretiseringen av yrkesopplæringen, men når antall timer til fellesfagene ligger fast og over $80 \%$ av læreplanmålene er av praktisk karakter, er det vanskelig å hevde at den formelle læreplanen skulle være skyld i at yrkesopplæringen oppfattes som mer teoribasert. Dette må oppfattes som en myte som stadig gjenfortelles. Læreplanmålene gir handlingsrom for praktiske læringsaktiviteter, men mye vil avhenge av hvordan den enkelte skole organiserer opplæringen slik at ikke klasserommet blir den nye læringsarenaen i yrkesopplæringen.

\section{Kilder}

Aadland, C. (2011). - Mindre teori, mer praksis. Bergens Tidende. Hentet fra http://www.bt.no/nyheter/valg/--Mindre-teori_-mer-praksis-2568111.html?xtor=RSS2

Andersen, K. (1999). Allmennutdanning og yrkesutdanning $i$ Norge : Hovedlinjer $i$ utviklingen av vidregående opplaering etter 1945. Kristiansand: HøyskoleForlaget.

Buland, T. (2010). Kunnskapssamfunnet, mer enn bare doktorgrader? Adressa.no. Hentet fra http://www.adressa.no/meninger/article1508146.ece

Dahlback, J., Hansen, K., Haaland, G. \& Sylte, A. L. (2010). Veien til yrkesrelevant opplaring fra første dag i Vgl: Sluttrapport. Høgskolen i Akershus. Kjeller.

Dale, E. L. (1993). Den profesjonelle skole. Oslo: Ad Notam Gyldendal

Duesund, L. (1995). Kropp, kunnskap og selvoppfatning. Oslo: Universitetsforlaget

Eikeland, O. (2006). Yrkeskunnskap og Aristoteliske kjennskapsformer. I Som gjort, så sagt?: yrkeskunnskap og yrkeskompetanse (s. 8-34). Lillestrøm: Høgskolen i Akershus.

Engelsen, B. U. (1998). Fagprøve og fagforståelse med fragmenter i et bilde av fagopplaring $i$ arbeidslivet (Gul serie nr. 3). Oslo: Universitetet i Oslo. Pedagogisk forskningsinstitutt.

Engelsrud, G. (2006). Hva er kropp. Oslo: Universitetsforlaget

Fuglestad, O. L. (1996). Teori, praksis og kunnskap i handling. Norsk Pedagogisk tidsskrift, (2), 86-94

Goodlad, J. I. (1979). The Scope of the Curriculum Field. I J. I. Goodlad (Red.), Curriculum Inquiry: McGraw-Hill Book Company.

Hegna, K., Dæhlen, M., Smette, I. \& Wollscheid, S. (2012). «For mye teori» i fag- og yrkesopplaringen - et spфrsmål om målsettinger i konflikt? - Europeiske utdanningsregimer og den norske modellen. Tidsskrift for samfunnsforskning, 53(2), 217-232. Hentet fra https://www.idunn.no/tfs/2012/02/for_mye_teori_i_fag- 
og yrkesopplaeringen et spoersmaal om ?mode=author info ID G864885980\&sk ipDecorating $=$ true

Hellne-Halvorsen, E. B. (2014). Skrivepraksiser i yrkesfaglige utdanningsprogrammer. (Doktorgradsavhandling). Institutt for lærerutdanning og skoleforskning, Det utdanningsvitenskapelige fakultet, Universitetet i Oslo, Oslo

Hiim, H. \& Hippe, E. (2001). Å utdanne profesjonelle yrkesutфvere - Yrkesdidaktikk og yrkeskunnskap. Oslo: Gyldendal Norsk Forlag.

Hiim, H. (2013). Praksisbasert yrkesutdanning: hvordan utvikle relevant yrkesutdanning for elever og arbeidsliv? Oslo: Gyldendal akademisk

Horneland, A. (2014). A vite og kunne : En dokumentanalyse av laereplaner og styringsdokumenter, Institutt for Pedagogikk, Universitetet i Oslo). Oslo. Hentet fra https://www.duo.uio.no/bitstream/handle/10852/43060/Horneland Master.pdf?sequen ce $=1 \&$ isAllowed $=\mathrm{y}$

Kirke, undervisnings- og forskningsdepartementet. (1996). Vidaregåande opplaering etter Reform 94. (1996). Regjeringen.no. Hentet fra https://www.regjeringen.no/no/dokumenter/Vidaregaande-opplaring-etter-Reform94/id87404/

Kristiansen, H. M. \& Hjørland, B. (2013). Litteratursøgningens metodik. I C. G. Johannsen, \& N. O. Pors (Red.), Evidens og systematisk reviews: En introduksjon. Danmark: Samfundslitteratur

Lindbekk, T. (2012). Fånyttes kunnskapspolitikk: Fra Reform 94 til Kunnskapsløftet: Reformer og målkonflikter i norsk utdanningspolitikk. Nytt Norsk Tidsskrift, 29(4), 372-381.

Lindgren, S. (2011). Tekstanalyse. I K. Fangen, \& A.-M. Sellerberg (Red.), Mange ulike metoder. Oslo: Gyldendal Akademisk.

Lotherington, P. B. (2008). Evaluering av "Kunnskapslфftet” for byggfagene. Hentet 21.10.2015 fra http://byggmesteren.as/2008/11/07/evaluering-av\%E2\%80\%9Dkunnskaps1\%C3\%B8ftet\%E2\%80\%9D-for-byggfagene/

Lysberg, M. \& Kihl, J. (2015, 22.01.). Ut mot teoritung skole. Klassekampen. Hentet fra http://www.klassekampen.no/article/20150122/ARTICLE/150129989

Laereplan for den videregående skole. Del 1. Generell del. (1983). Kirke, utdannings- og forskningsdepartementet. Oslo: Gyldendal.

Laereplan for den videregående skole. Del 1. Generell del. (1976). Kirke, utdannings- og forskningsdepartementet. Oslo: Gyldendal.

Lareplan for videregående opplaring. Studieretning for hotell- og naringsmiddelfag. Studieretningsfagene i grunnkurs hotell- og naringsmiddelfag. (1993). Kirke, utdanning og forskningsdepartementet. Hentet fra http://www .google.no/url?sa=t\&rct=j\&q=\&esrc=s\&source=web\&cd=1\&ved=0CBwQ FjAAahUKEwjhnv6pkrrIAhWFCiwKHdV_Bos\&url=http\%3A\%2F\%2Fwww.udir.no \%2Fglobalassets\%2Fupload\%2Flarerplaner\%2Fhotell_naring\%2F5\%2Fhotell_og_nar ingsmiddelfag_gk.rtf\&usg=AFQjCNFhDv6iphMFL-fwF8HpTszZ-VTdjw

Løvlie, L. (1974). Pedagogisk filosofi for praktiserende lærere. Pedagogen 22 (1)

Mausethagen, S. (2007). Mennesket leser for å spørre. En diskursanalyse av de 
grunnleggende ferdighetene som et sentralt element $i$ norsk utdanningspolitikk, og refleksjoner over utfordringer og snublesteiner i Kunnskapslфftet. (Masteroppgave). Det utdanningsvitenskapelige fakultet, Universitetet i Oslo, Oslo. Hentet 28. september $2016 \mathrm{fra} \mathrm{https://www.duo.uio.no/handle/10852/30989}$

Molander, B. (1993). Kunskap i handling. Göteborg: Daidalos.

Møllen, K. S. (2008). Utkast. Beskrivelse og vurdering av husstellfaget i den videregående skolen i Norge. Historiske forutsetninger - Utdanning i videregående skole.

Oppen, T. (2012). Skylder på systemet. Romerikes Blad. Hentet fra http://www.rb.no/lokalenyheter/skylder-pa-systemet/s/1-95-6237313

Ryle, G. (1949). The concept of mind. Storbritannia: Routledge Ldt. (Reprint 2009).

Rød Ungdoms landsstyre. (2013). Nei til teoretisering av yrkesfag. Hentet 21.10.2015 fra http://rødungdom.no/nyheter/nei-til-teoretisering-av-yrkesfag

Schatzki, T. R., Knorr-Cetina, K. \& Savigny, E. v. (2001). The practice turn in contemporary theory. New York: Routledge.

Schön, D. A. (1983). The reflective practitioner: how professionals think in action. New York: Basic Books.

Sjøberg, J. (2014, 31.08.). Halvparten av yrkesfagelevene hopper av. Aftenposten. Hentet fra http://www.aftenposten.no/okonomi/Halvparten-av-yrkesfagelevene-hopper-av$\underline{7684680 . \mathrm{html}}$

Solberg, D. (2014). NHO: Praksis større verdi. Hentet fra http://byggmesteren.as/2014/01/08/nho-praksis-storre-verdi/

Solheim, T. (2009). Opplæring i yrkesfag. Teori - praksis. Bedre skole, 4, $27-30$.

Spetalen, H., Johansen, E. M. \& Johnsen, K. L. (2014). Kvalifisering til læretid - Ikke bare et spørsmål om teori eller praksis i skoleopplæringen. Nordic Journal of Vocational Education and Training, 4.

St. meld. nr. 33 (1991-1992). Kunnskap og kyndighet: Om visse sider ved videregående opplacing. Oslo. Hentet fra https://www.stortinget.no/no/Saker-og-

publikasjoner/Stortingsforhandlinger/Lesevisning/? $\mathrm{p}=1991$ 92\&paid=3\&wid=b\&psid=DIVL1572\&pgid=b_1407

St. meld. nr. 30 (2003-2004). Kultur for laering. Oslo: Utdannings- og forskningsdepartementet.

Stray, J. H. (2009). Demokratisk medborgerskap i norsk skole? : en kritisk analyse. (Doktorgradsavhandling). Pedagogisk Forskningsinstitutt, Universitetet i Oslo, Oslo. Hentet 20. februar 2017 fra https://www.duo.uio.no/bitstream/handle/10852/30460/AvhandlingJHStray.pdf?seque nce $=1 \&$ isAllowed $=\mathrm{y}$

Støren, L. A., Skjersli, S. \& Aamodt, P. O. (1998). I mål? Evaluering av Reform 94: Sluttrapport fra NIFUs hovedprosjekt (NIFU Rapport 18). Hentet fra http://www.nifu.no/files/2013/05/NIFUrapport1998-18.pdf

Thagaard, T. (2009). Systematikk og innlevelse : En innføring i kvalitativ metode (3. utg.). Bergen: Fagbokforlaget.

Utvær, B. K. \& Rokkones, K. (2012). Teorifag er ikke problemet. Adressa.no. Hentet fra http://www.adressa.no/meninger/article1827292.ece 
VILBLI.NO. Fylkenes informasjonstjeneste for s $\phi$ kere til videregående opplaring. Hentet 11.10.2015 fra http://www.vilbli.no/?Program=V.RM\&Side=1 .2\&Kurs=V.RMRMF1--- V.RMMFG2----

Wasenden, W. (2001). Noen synspunkter på forholdet mellom allmennfag og yrkesfag i yrkesutdanningen i tiden før reform 94. I W. Wasenden (Red.), Yrkesretting som pedagogisk prosess (s. 5-21, Rapporter og utredninger nr. 4/2001). Stabekk:

Høgskolen i Akershus. 